\title{
電極サンドイッチ形による耐トラッキング 性試験結果の検討
}

$\begin{array}{lllll}\text { 武蔵工業大学 } & \text { 藤 } & \text { 川 } & \text { 英 } & \text { 司 } \\ \text { 武藍工業大学 } & \text { 唐 } & \text { 沢 } & & \text { 繁 } \\ \text { 武蔵工業大学 } & \text { 沼 } & \text { 倉 秀 } & \text { 穂 }\end{array}$

\section{1. まえがき}

近年多種の高分子材料が開発さ扎，きわわて督秀な 絶縁材料として広く用いられるようになったが，それ につれていままでの無機材料には見られなかった問題 が発生した。トラッキング少化に関する問題もたの つである。

トラッキングを発生する機構ならび代少化現集など 比関しては電気学会技術報告(1)(2)にも解説されている ととろであるが，トラッキング劣化を起こす表面の状 態が 2 種類あるととから，絶縁材料の耐トラッキング 性を評洒する試験方法屯湿潤状態之乾燥状態とにお る方法とに分けられている。前者は䋓縁物の表面を活 損液で湿らせてトラックの形成を加速させる屯ので， 電解液滴下に上る方法 (IEC 推奖法, ${ }^{(3)}$ DIN 法( ${ }^{(4)}$ ), Dust and Fog Test, ${ }^{(5)}$ 污損液倾斜平面試験方法 ${ }^{(6)} な$ よ゙, 㣪者は高電圧小電流耐アーク性試験方法, (7)コンデ ンサの間欠放電による耐トラッキング性試験方法, ${ }^{\{8\}}$

トリガ放電を利用した乾式低電圧酎トラッキング性試 䮦方法 ${ }^{(9)}$ などが提案されている。

てのうち湿式法は，わか泪では一応 IEC 推奖法と Dust and Fog Test が広く知られている。IEC 推奖 法は試呀が簡単に行なえること，再現性が比較的良い

The Investigation of Test Results by the Electrode Sandwich Type Tracking Resistance Testing Apparatus. By H. FUJ1. KAWA, Member, S. KARASAWA, Member \& H. NUMA. KURA, Member (Musashi Institute of Technology)

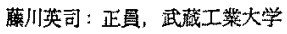

唐次 繁：正員，武藏工業大学

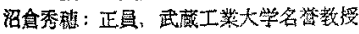

こと，実際の曘気㙨器に使用された場合との相関性が 良いととなどの利点があるので，䉓気学会侸設され た絶緑材料耐トラッキング性試験法専門委員会に术い てもこの方法を標準法としているのであるが，反面， 耐トラッキング性の良い材料の判定が困難であるとと が欠点己されている。また Dust and Fog Test は人 工污損の状態汃自然の污提状態之似ていることが陚駼 方法としてすぐれているが，污損状態の調節が困䙵で あ石こと，試験時間が長いという久点が指摘されてい る。

筆者らの研究室に批て開発した電極サンドイッチ 形耐トラッキング性試踰方法は試験条件の謂節がきわ めて容易であり，かつ耐トラッキング性の啰秀なるが ため IEC 推奖法で性判定汃困蜼とさ机る材料の試験 も可能であり，さらに短時間で試験結果が得られると いう特長を有する方法である上思加れるしかし，再 琴性の点で多少難点があり，また事際の電気機器に使 用するときの海損状態上は差があることが点と見ら れるのであるが, ${ }^{(2)}$ 後者の点に関しては他の多くの試 唤方法といえぞも大同小翼の久点は免れないのであっ て，笋者らの試験方法によって各種の材料間の比較に は十分に役だつ方法と考至られる。

そこで筆者らは，この電極サンドイッチ北法により 試験条件を変えて各種絶縁材料のトラッキング破壊試 䮩を行ない，IEC 推奖法に上る結果之比较すること により本力法の検討を行ない，あわせてトラッキング 破燷時間に影響を与える要因について考察を助党たの で，その結果を゙報告する。 


\section{2. 電極サンドイッチ形酎トラッキング性 試験装置の説明}

トラッキング加速劣化試験では試料表面の污提状態 によって得ら机る結果が大いに影響されるので，污損

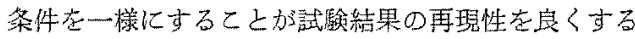
ために欠かせない要因であ。前述の各試験方法を見 ると，いずれ类試験ふれい気の調節のむず加しさが指 摘さ机る。その点，電淟サンドイッチ形法活毛細管現 像を利用して污損状態を作るので，電解液面の高さを

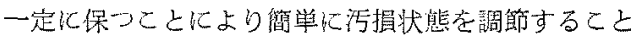
ができる。

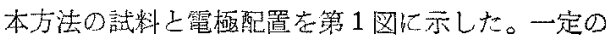
跎離 $(8 \mathrm{~mm}$ ) 隔てて突き合和せた 2 枚の平板電極 (約 $40 \times 10 \times 0.2 \mathrm{~mm})$ 老 2 枚の試験片 $(50 \times 50 \mathrm{~mm}$ ，愿さ 約 $2 \mathrm{~mm})$ にてはさみ，試料面を垂直にして2枚の電 極が上下になるように配置する。とれを電解液中に浸 世きするると試料面間（間隔 $0.2 \mathrm{~mm}$ ）行は毛細管現象 水よって電解液が上昇して，試料表面が常に如らされ ていることになる。こうして人工的作った污損状態

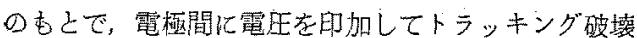

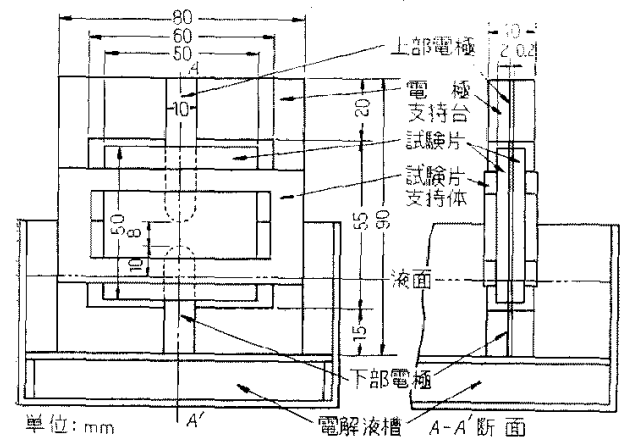

第 1 図 電極之試験片の配置

Fig. 1. Test apparatus containing of electrodes and specimens.

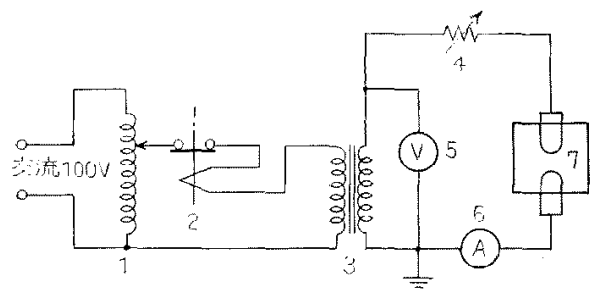

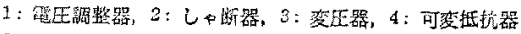

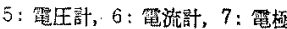

第 2 图試験回路

Fig. 2. Test circuit.
を発生させるものである。試験回路を第 2 図に示し た。

試驗条件は次の上うにした。本方法が電極を試料で はさんで電解液中に浸し，毛細管現象を利用して試料 表面を始らすという简便な装置を用いた方法だるるか ら，電解液の液面の高さが試験結果のばらつきに影響 することは当然予想される。元てで，液面の高さを梦 化させて試験莸行なった結果を第 3 図に示した。ての 結果方ら，液面の水位㐬下部電極の上端加ら下方八 $10 \mathrm{~mm}$ の高さとすると，トラッキング破壊するまで の時間が最短で，結果のばらつきも実験を行なった籍 曲では一番少なく，この值が適当と考えた。電極形状 は雨電極の対向している端在上屯に半円にしたすのを 用いた。

なお，比較のために先端に約 90 度の角度をむって 尖らした電極学用いて見たが，㣪者では電極先端部に アークが発生しやすく，試験結果のばらつきが多いと とから前者のほうが適当であるととがわかった。電 極間隔は $8 \mathrm{~mm}$ - - 定にした。電解液は IEC 推罢法と 同じ監化アンモニウム溶液とした。試験は電圧印加後 30 分以上印加し続けて㿝破壊しない，なるべく高い 電圧と $2.0 \mathrm{kV}$ までの間の電生で行なうことにした。 試験電王は次の上うに印加した。まず調整霓任として $1.0 \mathrm{kV}$ を印加して試駼を開始する。その後，1分し とに印加電生を $0.25 \mathrm{kV}$ （むし $0.25 \mathrm{kV}$ 電圧完上界 させると試験電圧より高くなる場合には試虽䉓圧にな るまでの値)ずつステップ状に上昇させて数分後に試 験電任にもっていく。その後は破賟するまで一定の電 压を維持する。ただし，記験電圧が $1.0 \mathrm{kV}$ 以下の埸 合 [具体的には試料 $(E)$ の場合〕には調整電圧として $0.5 \mathrm{kV}$ 加引試験を開始した。回路条件として試験前 に電極を短絡したとき $1 \mathrm{~A}$ の䉓流が流れるように調整 してある。

トラッキング破墙の判定方法は，破壊しないときの 電流佔が $0.1 \mathrm{~A}$ 程度であるこ々から，0.8A 以上の電

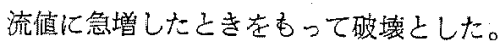

本方法により，絶縁材料の耐トラッキング性を判定 するには詿験電生と破壊するまでの時間との関係をグ ラフに描き，規定の時間に対応する電圧〔相対トラ。 キング電圧: Relative Tracking Voltage (以下 RTV で表わすてとにするりをもって評何することにした。 この試匰では IEC 推奖法と比較する意味もあって 便宣上 25 分値をとった。

侵食性材料の場合には電壬印加後貫通方るいは燃烧 により破壊するまでの時間を測定した。電圧を的加後 25 分を経過してす破壊しない材料については，その 


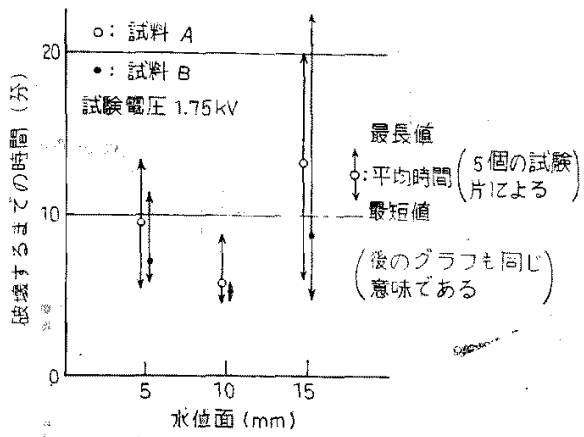

籍了图 電解腹の水位面を変化させたときの 試駼結果

Fig. 3. Test results at variable surface level of electrolytic solution.

洔刻㐳扔いて電圧を切り，その後で最大侵食深さを测 った。試験做数は同一の条件にて 5 個について行な い，その平均値をむって表加した。

この試験条件の下で，本方法に上り絶縁材料のトラ ッキング破垻試験を行なった。あわせてトラッキング

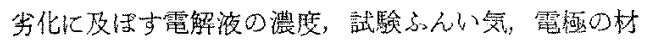
質，電圧の影響を检討した。

\section{3. 試 験 結 果}

本方法に上る試駼結果壳数多く古る他心絶縁材料の

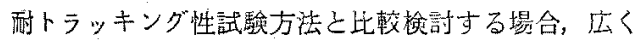
知られている多くの方法と対此するととが試馱力法相 互間の対応老考元て望ましいととであるが，ここでは わ於国纪衿てきとして推翼されている IEC 推奖法

第 1 表 試料とその耐トラッキング性の值

Table 1. Tested materials and its tracking resistance values.

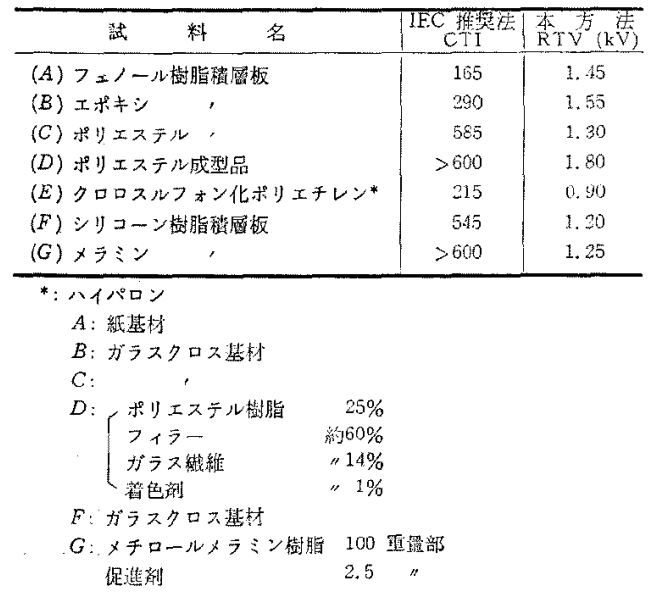

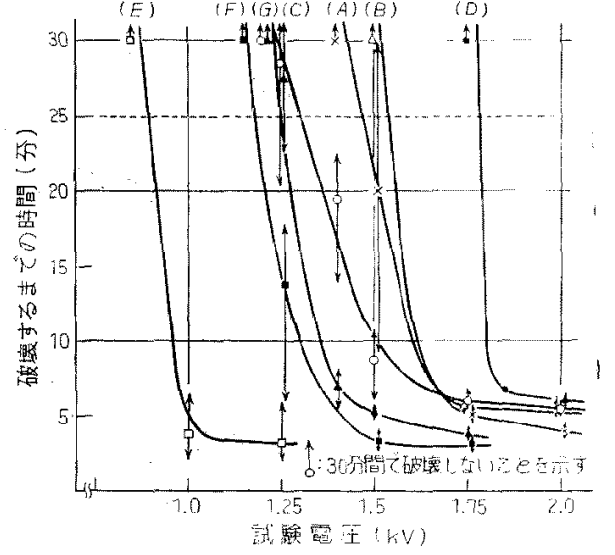

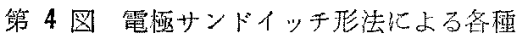
試料の試験結果

Fig. 4. Test results of several kinds of specimens by electrode sandwich type tracking resistance testing apparatus.

との比較を試みるととにする。

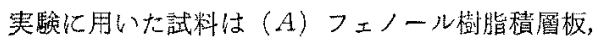
(B) エポキシ樹脂勫層板，(C) ポりエステル樹能皘 層板，(D) ポリエステル成型品，(E) クロロスルフ ォン化ポリエチレン， $(F)$ シリコーン樹脂棈䙓板， $(G)$ メラミン樹脂積層板， $(H)$ ポリメチルメタアク リレート（I）塩化ビニル，(J) ポリエチレン， $(K)$ シリコーンゴムの 11 種類で劣る。以下 $(A) \sim$ $(K)$ の記号を用いて表わすととにする。 $(A) \sim(G)$ はトラッキング破壊を起こす陚料であり，てれらの試

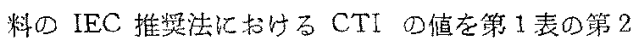
行目に示した。

本方法により各璉試料についてトラッキング破壊試

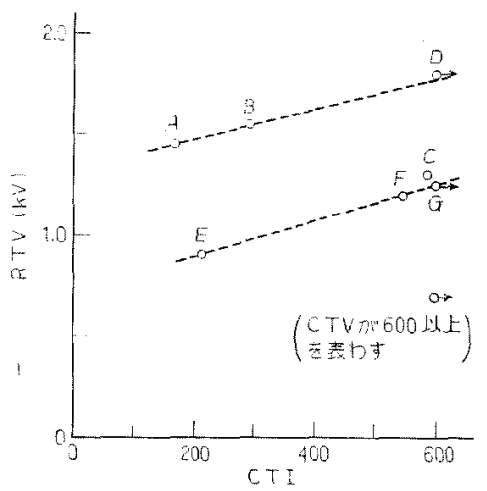

第 5 图 RTV 亡 CTI の比校

Fig. 5. The comparison between RTV and CTI. 
試料 (A)

電石: $1.5 \mathrm{kV}$

破许洔間：18分15秘

試料 $(B)$

它压: $1.6 \mathrm{kV}$

破墩時間：13尔50飞

試料 $(F)$

電压: $1.25 \mathrm{kV}$

破壊時間：9 分30秘

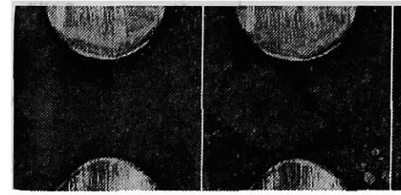

(a) 5 尔後

(b) 7 分後

(c) 10 分後

(d) 15 分後

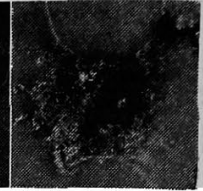

（e）破壊後

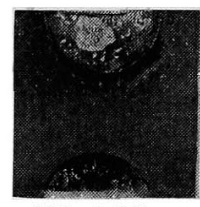

(f) 5 分後

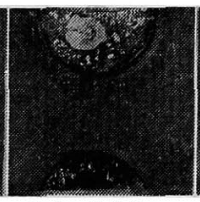

（g） 6 分後

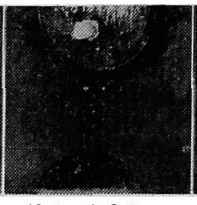

(h) 8 分後

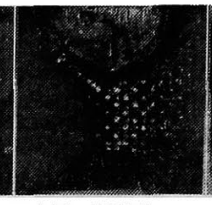

(i) 10 分後

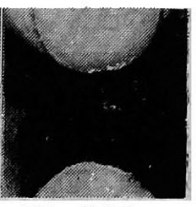

（j）破掖後

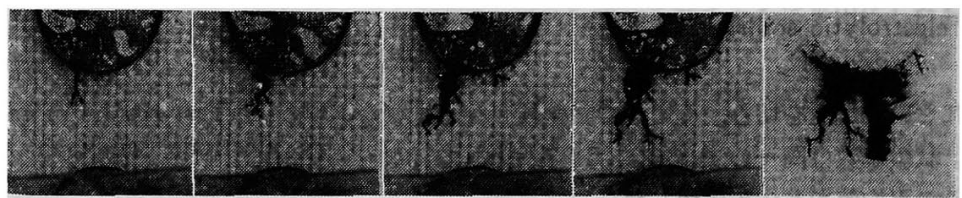

(k) 2 分後

（1） 4 分後

(m) 6 分後

(n) 8 分後

（o）破壊後

Fig. 6. The photographs of specimen surface.

験を行ない，その結果を第 4 図に示した。このグラフ から等者らの提案する RTV の值を求めて第 1 表の 第 3 行目に示した。本方法による試験結果を IEC 推 奨法による結果と比較しやすくするために，各種試料 の RTV と CTI との值の関係をグラフにすると第 5 四のようになった。

この結果をみると，(D)および $(G)$ は IEC 推奨法 では CTI が 600 以上であり，電圧をそれ以上高くす ると電極間にアークが発生しやすくなるために CTI の值が求められず，したがって，両者の耐トラッキン グ性の判定が困難であったが，本方法によれば両者と あトラッキング破壊させることが可能であり，(D)の ほうが $(G) よ り$ 耐トラッキング性が良いという結果が 得られ，評価する範囲が広げられたといえる。

次に $(D)$ および $(G)$ 以外の試料の耐トラッキング性 の順位についての RTV 值と CTI 值との相関性は,

第 5 図から見られるように試料によっては相関性を持 つ群 $(E, F, C)$ と相関性を持たない群 $(A, B)$ のあるこ とを示している。この原因は，むともと IEC 推奖法 と電極サンドイッチ形法とではトラッキング劣化を起 こさせる状況にある程度相遙があるためによるものと 考えられるが，その相違点加試料の種類によっては，

それの受ける影響が著しい場合とそうでない場合があ る。以下, こ机らの点について考慮してみる。IEC 推 奖法では試料の配置は水平であるから, 試験中に発生.
した炭化生成物は表面に残りやすい。したがって，炭 化生成物を発生しやすいむのは CTI 值は低くなると とが予想される。これに対して電極サンドィッチ形法 では試料配置は垂直であり，かつ微小放電の発生ごと に毛管現象により電解液が移動して炭化生成物が持ち 去られやすい。

第 6 図にその状況を示した。（a ），(b)，（c）执よ び (d) 図は試料 $(A)$ について電圧 $1.5 \mathrm{kV}$ 印加時の試 料表面の変化を示す写真である。(a)図は上部電極付 近の一部にトラックができ始めたてとを示す。(b)図 では遊離した炭素がなくなっている。(c)図はしばら くしてさらに炭素が遊離したてとを示す。このような 状態をくり返しながら表面が徐々に劣化され，遂には トラックが電極間を短絡して破壊へと進むことにな る。（d）図はその状態を示している。トラッキング破 壊後, 支持体から試料を取り出してその表面を観察す る上，(e)図に見られるように一部炭素が洗い流さ れ，侵食されているのが認められた。試料( $(B)$ につ てもほぼ同様であった。〔( f $) 〜(\mathrm{j})$ 図〕

一方, $(\mathrm{k}) \sim(\mathrm{n})$ 図は試料 $(F)$ について電圧 1.25 $\mathrm{kV}$ 印加時の表面の写真である。この試料の場合, 一 度炭素が遊離すると表面にかたく付着して, トラック が時間の経過とともに少しずつ進展して破壊となる。 （）図に見るように破壊後の表面には炭素が洗い流さ れた形跡はない。このととから試料 $(A),(B)$ に生じ 
第 2 表 侵食性材料の試験結累

Table 2. Test results of materials which are to be failed by erosion.

\begin{tabular}{|c|c|c|c|}
\hline 赫料 & 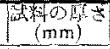 & IEC 推垡法 & 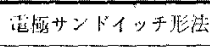 \\
\hline$H$ & 2.10 & $\begin{array}{c}0.041^{*} \\
(0.013)\end{array}$ & 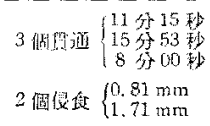 \\
\hline$I$ & 2,60 & 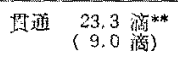 & 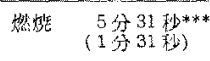 \\
\hline$J$ & 210 & $0.008 *(0.004)$ & $0.283 *(0.186)$ \\
\hline$K$ & 1,95 & $0.003 *(0.0005)$ & $0.008 *(0.0018)$ \\
\hline
\end{tabular}

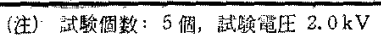

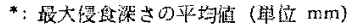

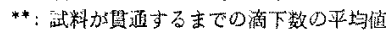

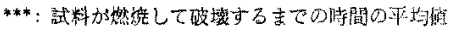

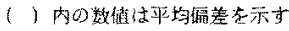

试料 H:ポリメチルメタアタりレート

I: 壏化ビ三ル

$J:$ ポリチレン

K:シリコーンゴム

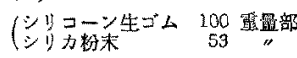

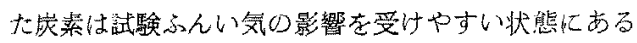
ととが加る。本方法はその表面加常似妨され，加 つ洗われる状熊で実用に供される上うな材料在試駼す る場合に対しては特に有效である。フ.ルール樹脂が 他より亮く評洒されるという結果になったのは包上 のためと考艺られる。

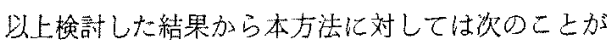
むえる。

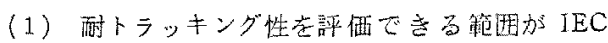
推奖法より底い。

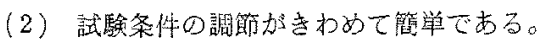

(3) 斌験結果力短時間で得ら札る。

ただし，IEC 推装法に基つく試娩結果己比校する 場合，試験のふんい気が異なる関係て，必ずし测定 結果の相関性加あるとは隄らない場合むある。

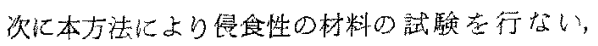
その結果を第2表に示した。IEC 推奖法に上る試馱 で，試験電压 $600 \mathrm{~V}$ でもトラッキング破㙍しない材

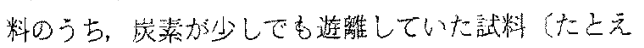
ば(D)と(G)了は本方法によればトラッキング皮壊し

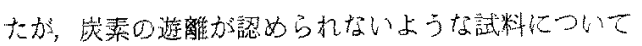

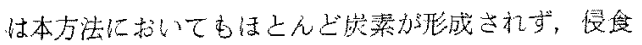

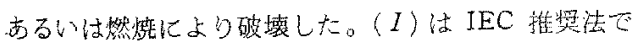

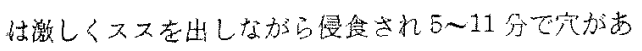

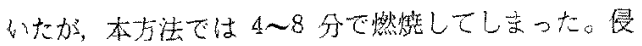
食により破燷した試料は IEC 推奖法上同永, 最大侵 食梁さ它測定して比校したが，本万法による試験では いずれも最大侵食深さが深くなっており，(H)ては宸
素が表面に付着している香の屯あった。いずれにし ろ，侵食悗材料の耐トラッキング性老評洒するのに， 現在の上こる鼠大侵食㴗さによって判定することにし てあるが、今後はより良さ力法加提案されるとしが望 まれるとこるである。

\section{4. トラッキング破壊時間に影響を及ぼす要 因について}

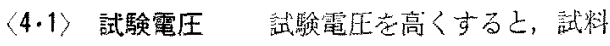
の温度を上羿させる源でおるジュ一ル熱は大となるう え，微小放笔のエネルギーあ大きくなるとからトラ

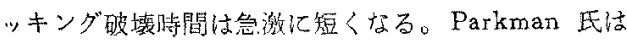

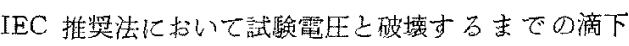

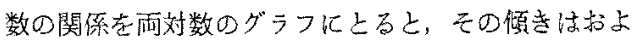
そー2であると発表した。 ${ }^{(10)}$ そして，逆二乗法則は卜 ラッキングの生成過程が電界の不連猛点で発するシン チレーションのパワに拣存していることを示すと述 ベている。籍者らの实験からこの值を求めて見ると， IEC 推買法に拉いてはー-2〜ー8であった。また電極

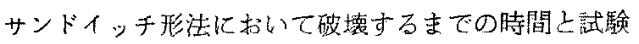
電圧との関係考西対数グラフに描いてみる上，その㥧 きは次の值となった。

(C): 約 -1.5

$(E):$ 約 -1.8

てれ外の武料: 的-4

(C) 於よじ (E)ば微小放電のエネルギー上り李他の要 因，た之方ば試料の温臀上昇に上り劣化時間に影響さ れるものと思わ机る。電压指数がー-4ということは，

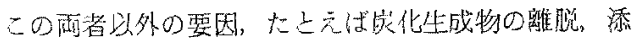
加剂の效果などが影響していると思われるが，詳細は 明らかではな。

〈4.2〉電極材料絶縁材料の䋓緑份化の問题在 取り报う䟢，電極材料の種類比よって出化の進行に変 北を及活すこしは広く認められている。トラッキング

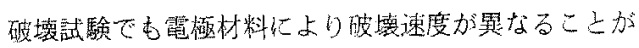
垶告されている。 表に示した。

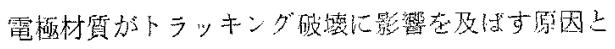
しては,

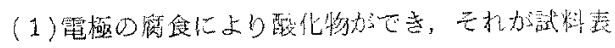
面に蓞積される磨合い

(2)蓺の放歇の邀い

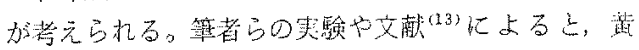
銅電栖によるほうがステンレス電桠によるよりる早く

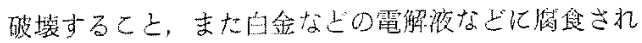

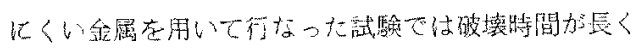




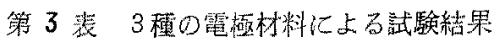

Table 3 . Test results with three kinds of electrode materials.

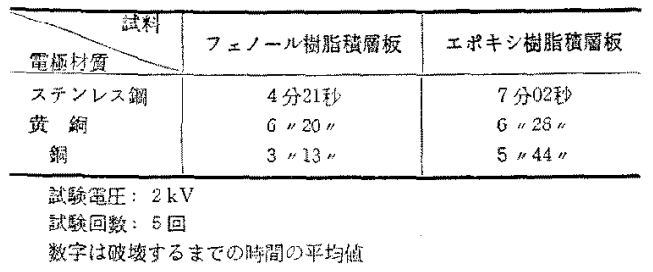

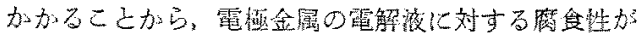

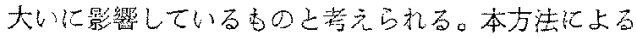

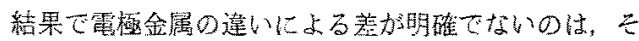

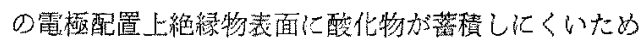
上考元る。

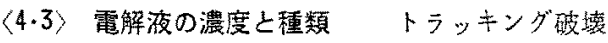

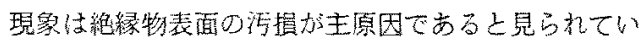
ることから，污損物䇫が霓解留の屯のを含えでいる埸

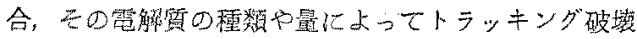

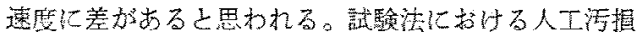
液は大気中心存在して總線物の表面を污損する物留上

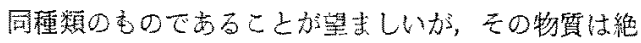
緑物为設置される場肺や状態により種杂雑多で方るた

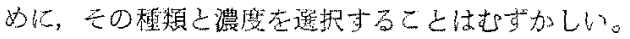

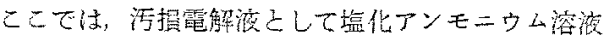

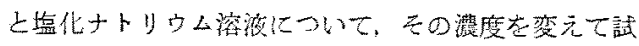

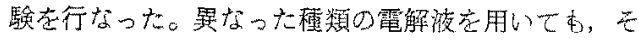
の薄電率が等しいと破㯖晆間はほぼ等しいしいう結果

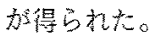

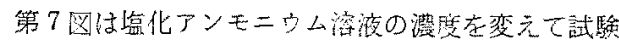

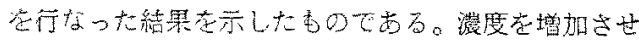
ると破填时間は短く拈り，RTV 委低くなった。濃度

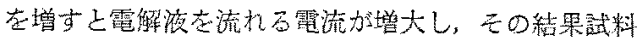

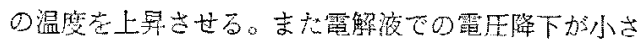
く场り，微小放電のエネルギーが大きくなるために教

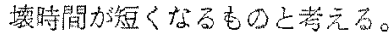

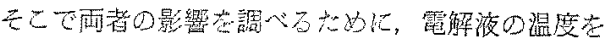

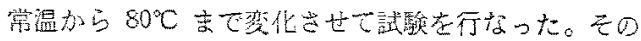

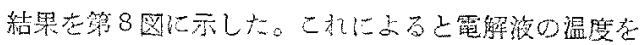
高くすると破颠時間付短くなった。しかしなが，温

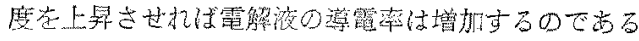

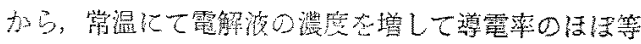

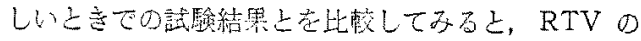
统はだいない等しかった。ま地電解液の温度を变え，

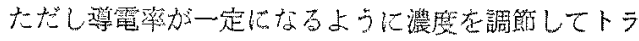

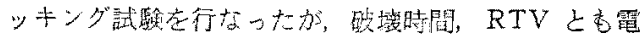

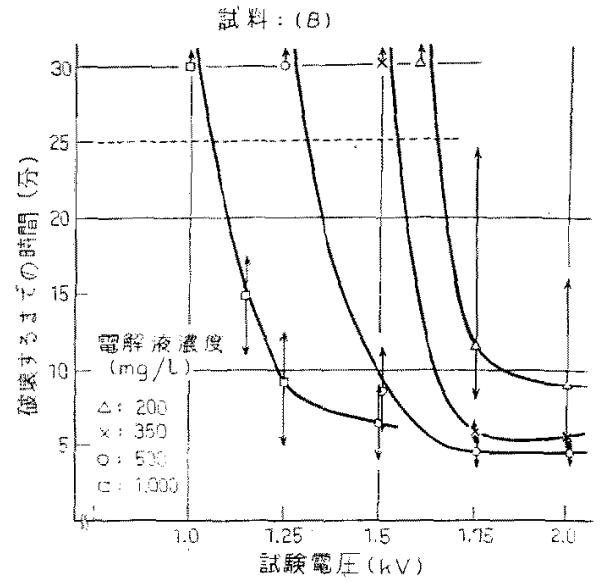

第 7 図 電解液の濃度を变化させたとさ

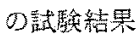

Fig. 7. Test results at variable concentration of electrolytic solution.

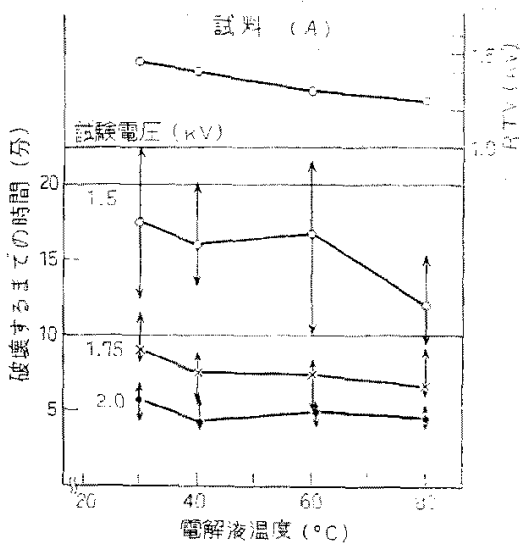

第 8 四 電解液の温度を変化ざせたるき

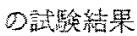

Fig. 8. Test results at variable temperature of electrolytic solution.

解椣の温度には影響されなかった。

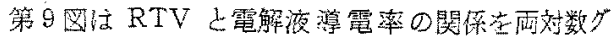

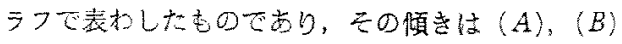
上吾 0.4 くらいであった。

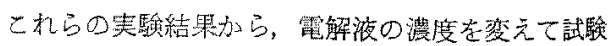

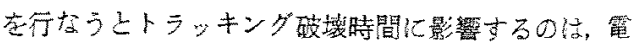
王四加中試粗の温度上舁の割合そのbのがトラッキン

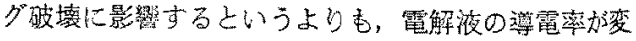
化したてとに上り電極間を流れる電流の大きさが変わ

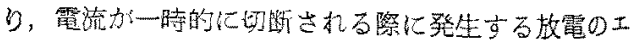




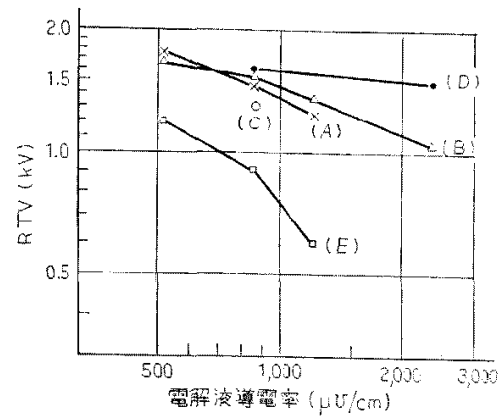

第 9 図 電解液篔電率之RTV O関俰

Fig. 9. The characteristic relation between conductivity of electrolytic solution and RTV.

ネルギーの大きさの変化のほうがよりトラッキング破

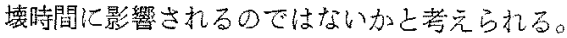

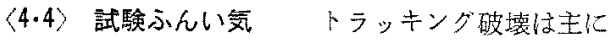
絶緑物表面加污損され，さらに湿った状態で発生する と考えられているから大気中に和ける破燷である。し かし，最近のように不活性ガス定封入したケーブルが 使われると，大気中とは異なったるんい気中でもトラ ッキング破畷することが考えられる。また加速多化証 験という観点からみても大気しは異なったふんい受中

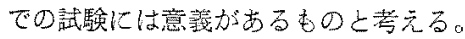

そこでまず減压したふんい気中でトラッキング試 験老行なった。その結果を第 10 図に示した。減在す るにつれて破槡时閐か短くなるのは，减压することに より放電加起こりやすくなるためと考えら机る。次に

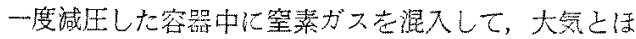

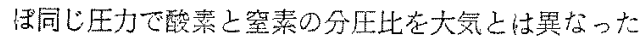
状㦔のふんい気中にてトラッキング破塄試験を行なっ た。第11图にこの結果老示した。試䁩電压が $1.5 \mathrm{kV}$

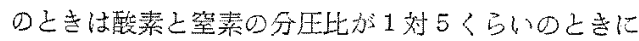
破填するまでの時間保最短之なった。窒䕀の多い頜域 では：シンチレーションによる材料の熱分解が覆素量

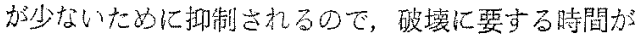
長いもの上考えられる。一方，酸素の多い領域におい ては絶緑物表面加ら尔解乚た生成物力酸化される作用

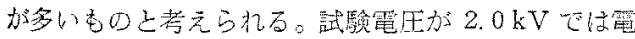
極闃でフラッシオーハしやすくなり，したがってトラ ッキング破維するまでの㭙間はふんい気によりほとん ビ影㭚されない。

\section{5.むすび}

この諭文は電極サンドイッチ形期トラッキング性融

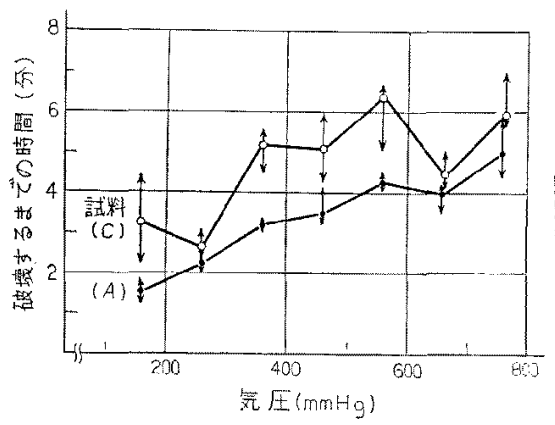

節 10 図 減圧したふんい気中での試路結果

Fig. 10. Test results in low pressure sell.

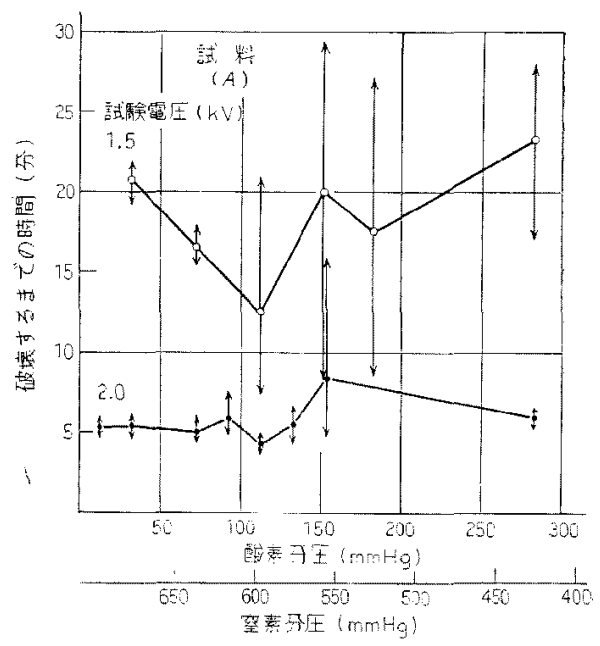

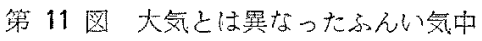
での試驗結果

Fig. 11. Test results at different atmosphric conditions.

駺方法により各種材料の試駼を行ない，本方法に上る

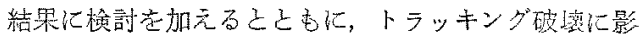
響を及は方要因について述へたむのでする。 本方法は，

(1)評傮できる籍四加 IEC 推奖法より広い

(2)試駼条件の調節がきかるて䌪筆でする

(3)試駰結果が短時關で得られる

などの利点起有しているす法であるとい无。

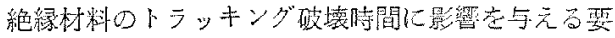
因について，䉓㥛サンドイッチ形法に上り检討を加え

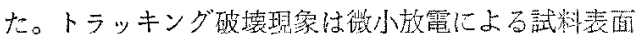

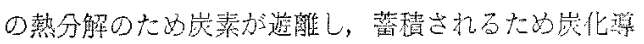

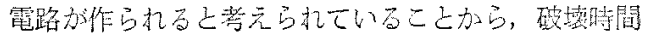




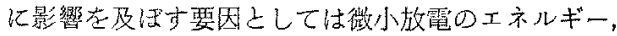
絶縁物の化学構造，試監在行なうふんい気なよ゙が大き い上考无られる。

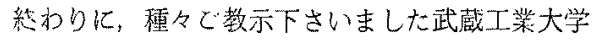
堺 考夫教授に感謝の意を表します。

(昭和 46 年 7 月 22 日等付，问 48 年 1 月 29 日再受付)

\section{文 献}

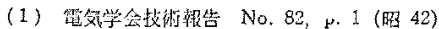

(2) 雷気学公技術种告 No, 86, p. 1 (昭 43)
(3) IEC Publication 112

(4) DIN 53480

(5) ASTM. D 2132-62 T

(6) ASTM. D 2303-64 T

(7) 電氮学会技術報告 No.7 (炤 30)

(8) 能登: 電学誌 82,559 (昭 37 )

(9) 日里·鈴木: 霆学誌 87, 200 (圆 42-1)

(10) N. Parkman: The British Electrical and Allied Industries Research Association. Reference L/T 409 (1962, May)

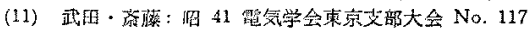

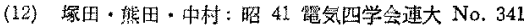

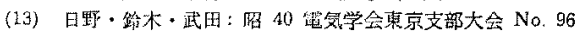

